\title{
THERMAL BEHAVIOR IMPROVEMENT OF BIODEGRADABLE FIBER POLYMER COMPOSITES POLYLACTIC ACID (PLA)/COIR USING ACEH'S BENTONITE
}

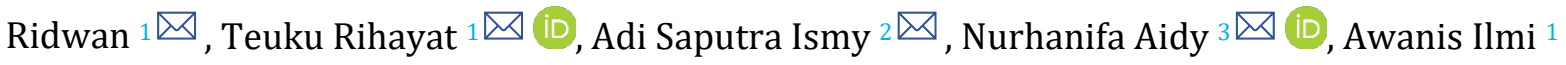

${ }^{1}$ Department of Chemical Engineering, Politeknik Negeri Lhokseumawe, Lhokseumawe, Aceh 24301, Indonesia.

${ }^{2}$ Department of mechanical Engineering, Politeknik Negeri, Lhokseumawe, Jl. Banda Aceh-Medan Km. 280,3, Buketrata, Mesjid Puntet, Blang Mangat, Kota Lhokseumawe, Aceh 24301, Indonesia.

${ }^{3}$ Departement of Renewable Energy, Universitas Malikussaleh, Tengku Nie, Cot Rd, Reuleut Tim., Muara Batu, Kabupaten Aceh Utara, 24355, Aceh, Indonesia.

Received 16 October 2021

Accepted 5 November 2021

Published 30 November 2021

\section{CorrespondingAuthor}

Ridwan, ridwan.pnl123@gmail.com

DOI

10.29121/granthaalayah.v9.i11.2021 .4381

Funding: This research received no specific grant from any funding agency in the public, commercial, or not-for-profit sectors.

Copyright: (C) 2021 The Author(s). This is an open access article distributed under the terms of the Creative Commons Attribution License, which permits unrestricted use, distribution, and reproduction in any medium, provided the original author and source are credited.

\section{ABSTRACT}

Research has been conducted on the manufacture of PLA Coir Bentonite composites. This study aims to examine the effect of PLA on mechanical strength with the addition of coir and bentonite fillers from North Aceh and Central Aceh. The sample formulations used were single polymer PLA/Coir and PLA/Coir with variations of filler Bentonite Aceh Utara and Aceh Tengah with 2, 4, 6 and 8\% respectively. The combination of PCa samples showed the highest bacterial colony growth rate, which was more than 100 colonies/gram during the 1 week testing period. In the PBATd filler mixture sample, the maximum bacterial test value was 65 colonies/gram and the minimum value contained in the PBAUa sample was 105 colonies/gram. The best tensile strength was obtained in the PBATc sample, namely $65 \mathrm{MPa}$. PBATd samples began to degrade at $370.15^{\circ} \mathrm{C}$ compared to PCa samples degraded at $280.21^{\circ} \mathrm{C}$. While the PBAUa sample began to degrade at a temperature of $282.11^{\circ} \mathrm{C}$. The surface structure of the PCa sample is more homogeneous because there is no bentonite filler mixture, but it is brittle and crumbles easily. For the PBATd sample, the surface structure is smoother and more homogeneous compared to the PBAUa sample.

Keywords: Polylactic Acid, Coir; Bentonite, Composites, Thermogravimetric Analysis (TGA)

\section{INTRODUCTION}

Research on environmentally friendly products is currently very popular, especially in the field of researchers or industrial players. Several polymer materials derived from environmentally friendly materials (biopolymers) have been produced, such as PHA Poly Hydroxy Alkanoate, Poly Hydroxy Butyrate and Poly Lactic Acid Chern et al. (2013).

Polylactic acid is one of the biopolymers belonging to polyester which has excellent biodegradable, biocompatible and recyclable abilities and the ability to process thermoplastic properties. Hin et al. (2012), Bino et al. (2015) PLA polymers have received a lot of attention and show great potential in bioplastic and biomedical applications among synthetic polymers. However, this biopolymer also has disadvantages, one of which is its low melting point, so that its heat resistance is not very good. Therefore, to overcome these weaknesses, PLA's properties can be improved by adding nano-sized fillers to form 
nanocomposites. Douglas et al. (2015) .

Based on several well-known references, one of the other fillers that are widely researched which is believed to be superior is bentonite. Bentonite is getting the most attention based on its ability to spread between layers widelyand its ability to expand. Bentonite is a mineral consisting of hydrated alumino-silicate crystals containing alkaline or alkaline earth cations in a three-dimensional framework. These metal ions can be replaced by other cations without damaging the structure of the bentonite and can reversibly absorb water. Bentonite can expand, have ionexchange properties, large surface area and easily absorbs water allowing its use as an adsorbent Hasnan et al. (2015), Najafi et al. (2012).

In addition, the surface acidity of bentonite associated with Brønsted acid and Lewis's acid allows the use of bentonite as a catalyst. In addition, to add high mechanical properties and biodegradable characteristics, Coir composites were added. This composite has several major advantages over conventional composite materials, such as environmental friendliness, light weight, low volumetric cost. Among natural plant fibers, coir is widely used in several applications. Teuku et al. (2019), Pradeep and Edwin (2015) The annual production of coconuts worldwide is about more than 40 million tons, which is about 50 billion coconuts. However, coconut coir fiber has a low cellulose content of about $42 \%$ and hemicellulose $0.3 \%$, with a high lignin content of $45 \%$ compared to other natural fibers. This fiber is one of the few natural fibers that are resistant to damage by salt water and is therefore relatively water-resistant. Purwaningsih et al. (2012), Shumigin et al. (2011), Suryani et al. (2016), Syamani et al. (2014), Suryani et al. (2018)

Among natural plant fibers, in this research, we will try to modify montmorillonite which is the result of purification from North Aceh Bentonite and Central Aceh Bentonite, which the mixing process will then carry out with PLA and Coir, where the resulting product will be compared with commercial products. The sample formulations used were PLA/Coir polymer with filler variations of Bentonite Aceh Utara 2, 4, 6 and 8\% and PLA/Coir polymer, which were given 2, 4, 6 and 8\% Aceh Tengah bentonite, respectively. The polymer characteristics with the addition of bentonite produce a more flexible and stronger polymer than the PLA/Coir alloy. The type of bentonite and its shape affect biodegradability, mechanical properties, thermal properties, and the morphological structure of the composite showing the increasing presence of molecules based on bacterial test results tensile test, TGA test (thermal) and SEM test. The addition of bentonite filler to PLA and Coir polymers can affect the material's mechanical properties. Tawakkal et al. (2012)

\section{MATERIALS AND METHODS 2.1. MATERIALS}

The main material used in this research is Poly Lactic Acid (Nature Work Co). The bentonite used comes from two different areas: bentonite from the Nisam area, North Aceh, and Bentonite from the Kab. Bener Meriah, Takengon, Central Aceh. Additional materials used in this study were Cetyl Trimethyl Ammonium Bromide/CTAB (Sigma Aldrich), Coconut Coir (Coconut Coir) and $\left(\mathrm{NaPO}_{3}\right)_{6}$ (Merck).

\subsection{METHODS}

\subsubsection{PREPARATION COIR}

The chemical treatment carried out is by alkalizing treatment on the fiber. The chemical treatment is done by soaking the fiber using $\mathrm{NaOH}$ (sodium hydroxide) and $\mathrm{KmnO}^{4}$ (potassium permanganate). Because $\mathrm{NaOH}$ and $\mathrm{KmnO}^{4-}$ are alkaline types, 
they are therefore used to remove the oil content (lignin layer) in fibers and reduce impurities that cause sera not to bond completely with the matrix/resin when the composite is printed, making the fiber last longer. longer against the attack of bacteria/microorganisms compared to fibers without immersion of $\mathrm{NaOH}$ and $\mathrm{KmnO}^{4-}$. Soaking the fibers with $\mathrm{NaOH}$ solution itself is done by adding $5 \% \mathrm{NaOH}$ and $5 \% \mathrm{KmnO}^{4-}$.

\subsubsection{SAMPLE PREPARATION}

Four containers were prepared for samples of the PLA/Coir mixture and bentonite. Mixed PLA/Coir and Bentonite Aceh Utara (total weight $=20 \mathrm{~g}$ ) with the

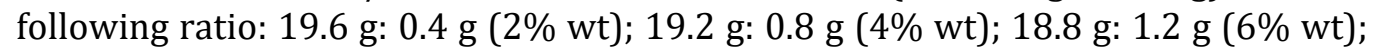
$18.6 \mathrm{~g}: 1.4 \mathrm{~g} \mathrm{(8 \% )}$. The mixture is melted in melt blending at a temperature of $140^{\circ} \mathrm{C}$. Then it will harden by itself to form PLA/Coir-Bentonite nanocomposite. PLA/CoirBentonite nanocomposite is then cut into granules and put into specimen molds according to ASTM 638 D Type IV Standard, then compacted by hot press with a temperature of $180^{\circ} \mathrm{C}$. PLA/Coir-Bentonite nanocomposites that have been molded are then dried in a vacuum oven at $60 \mathrm{oC}$ for 24 hours or dried in ambient air. Zulkifli et al. (2018), Rihayat et al. (2018)

\subsection{CHARACTERIZATION TECHNIQUE}

\subsubsection{BACTERIA TEST}

Microbial testing was carried out using a method that is often used, namely compost soil media. All samples were placed in a container filled with soil/directly in nature and then left until the degradation level obtained reached approximately two months until completely degraded and the changes in the sample were only seen to change for one month. Jaafar et al. (2019)

\subsubsection{PULL TEST}

Engineering tensile tests are mostly carried out to complement the basic design in-formation for the strength of a material and as supporting data for material specifications. In the tensile test, the test object is given an axial tensile force load which increases continuously, at the same time observing the elongation experienced by the test object. Zulkifli et al. (2018), Rihayat et al. (2018)

\subsubsection{THERMOGRAVIMETRIC ANALYSIS (TGA)}

TGA is the most common, simple, and fast technique for kinetics analysis for devolatilization processes. In principle, this method measures the reduction in the mass of the material when heated from room temperature to a high temperature which is usually around $900^{\circ} \mathrm{C}$. Rihayat et al. (2017), Azhar et al. (2021), Qamara et al. (2021) , Nurdiana et al. (2013).

\subsubsection{SCANNING ELECTRON MICROSCOPY (SEM)}

Scanning Electron Microscope (SEM) is an electron microscope that is used to view the image surface of a material; besides that, it can also provide information regarding the chemical composition of a material, both conductive and nonconductive materials. This microscope uses electromagnetic and electro static to control the incoming light and the appearance of the resulting image. Bhasney et al. (2020) 


\section{RESULTS AND DISCUSSIONS}

\subsection{BACTERIA TEST}

Bacterial testing was carried out using the ALT (Total Plate Number) method and biodegradation testing using the composting technique. The process of biodegradability can occur by hydrolysis (chemical degradation), bacteria/fungi, enzymes (enzymatic degradation), wind and abrasion (mechanical degradation), light (photodegradation). Fahmi and Hermansyah (2011), Ginting (2016), Ajeng and Dianita (2017) The time interval of the checks carried out in the sample testing lasted for $0 ; 3 ; 6 ; 9$; and 12 days by observing the development of the stained plate that has been placed Potato Dextrose Agar (PDA) as a growing medium for bacteria. The development of bacteria in 9 types of samples is shown in Table 1.

\begin{tabular}{|cccccc}
\hline \multicolumn{4}{|c}{ Table $\mathbf{1}$ Bacteria Test Sample } \\
\hline No & Sample & \multicolumn{4}{c}{ Day (\%) } \\
\hline & & $\mathbf{3}$ & $\mathbf{4}$ & $\mathbf{9}$ & $\mathbf{1 2}$ \\
\hline $\mathbf{1}$ & PCa & 74 & 93 & 119 & 130 \\
\hline $\mathbf{2}$ & PBAUa & 68 & 81 & 93 & 105 \\
\hline $\mathbf{3}$ & PBAUb & 62 & 70 & 84 & 92 \\
\hline $\mathbf{4}$ & PBAUc & 54 & 66 & 79 & 87 \\
\hline $\mathbf{5}$ & PBAUd & 41 & 50 & 63 & 70 \\
\hline $\mathbf{6}$ & PBATa & 59 & 74 & 84 & 96 \\
\hline $\mathbf{7}$ & PBATb & 53 & 69 & 72 & 84 \\
\hline $\mathbf{8}$ & PBATc & 46 & 51 & 61 & 71 \\
\hline $\mathbf{9}$ & PBATd & 39 & 47 & 55 & 65 \\
\hline
\end{tabular}

From Table 1, Microbial development during the testing process that occurred in PCa samples showed the highest colony growth rate, which was more than 100 colonies/gram during the 1 week testing period. This is because the composite is directly contaminated with air which contains various types of microbes that can affect the material both physically and chemically. The results showed that the PBAUTd sample had the lowest colony growth rate, 65 colonies/gram. It was followed by PBATa, PBATc and PBATd with colony growth rates of 96,84 and $71 \%$. Then the PBAUa, PBAUb, PBAUc and PBAUd samples obtained colony growth rates of $105,92,87$ and $70 \%$.

In samples without filler, the average structure change tends to be porous and darker because more filler is added. While the PLA/Coir combination polymer without bentonite filler mixture has a structure that tends to crack and has a color that is not so dark. This proves the collaboration of polymer alloys and filler alloys, which provide resistance to microbial degradation. Astika and Dwijana (2018)

\subsection{TENSILE STRENGTH TEST RESULTS}

Tensile strength PLA/Coir, PLA/Coir/Bentonite AU, PLA/Coir/Bentonite AT. The tests conducted show the variations of the polymer and its fillers, in research on the addition of bentonite fillers with a concentration of $2 \% 4 \% 6 \%$ to $8 \%$. But the

results obtained contradict the observations. 


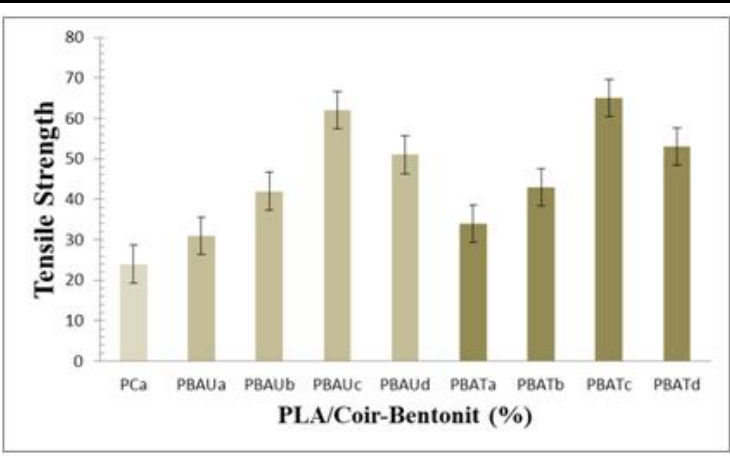

Figure 1 Graph of Tensile Test Results for Sample Formulations

Based on the test results, it can be seen that the addition of a polymer filler shows an increase in the properties of the composite. The new material produced shows an increase in the quality of its strength properties which are better than the pure PLA/Coir polymer without mixing. The PLA/Coir-Bentonitenanocomposite samples in each variation in the type and amount of bentonite filler used showed differences. The value of the tensile strength test is directly proportional to the number of fillers used. The more amount of bentonite mixed into the PLA matrix, the greater the value of the resulting tensile test, but if the filler is added with overload, it will experience a decrease in the tensile strength value. The results of the tensile test of the PCa sample, the tensile strength value of $24 \mathrm{Mpa}$ is brittle, then with the bentonite filler from Central Aceh region for each variation of 2, 4, 6 and 8\%, the tensile strength and stress at break values were higher at 34, 43, 65 and 53 Mpa. Compared to mixing with bentonite filler from North Aceh for each variation of 2,4, 6 and $8 \%$ of the North Aceh bentonite, the tensile strength values were obtained at 31, 42, 62 and $51 \mathrm{Mpa}$. The maximum value in the PBAUTd sample is 65 $\mathrm{MPa}$ and the minimum is the PBAUa sample with a value of $31 \mathrm{MPa}$.

\subsection{THERMOGRAVIMETRIC ANALYSIS}

Mass loss in the thermal test (TGA) occurs due to the decomposition process, namely the breaking of chemical bonds in the composite material. Fahmi and Hermansyah (2011), Ginting (2016). Figure 2 is a graph of the TGA test results for nine samples with the highest values in the previous test, namely PLA/Coir Coir without bentonite filler, PLA/Coir Coir/Bentonite AU variations and PLA/Coir Coir/Bentonite AT variations.TGA results showed an im-provement in the thermal stability of the biocomposites as nanoclay content was in-creased due to thermal barrier effects of nanoclays. Piekarska et al. (2017), Kurzina et al. (2020)

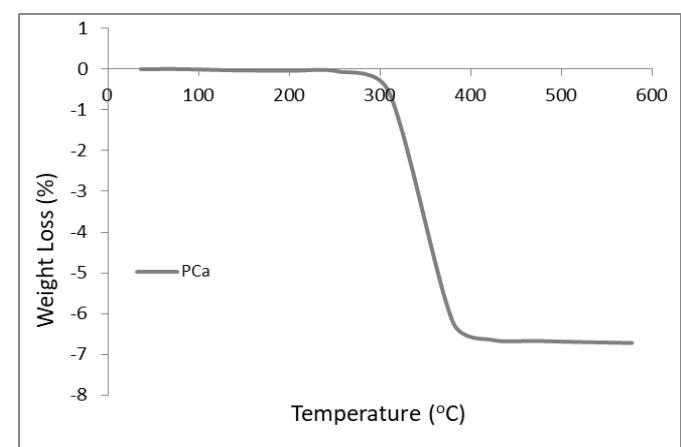

Figure 2 TGA Graph of Each Sample PCa (pure PLA) to Temperature 


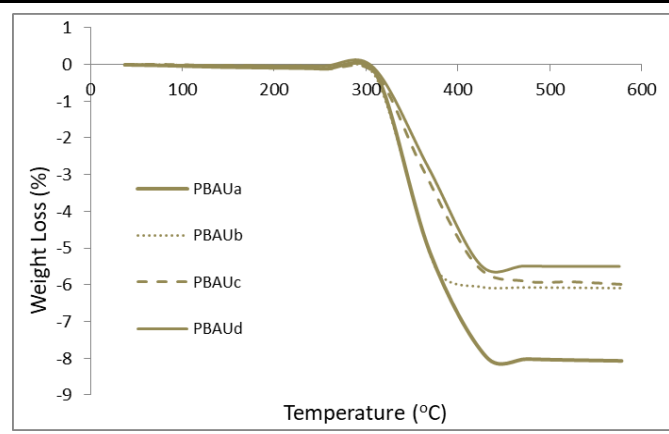

Figure 3 TGA Graph of Each Sample PBAU to Temperature

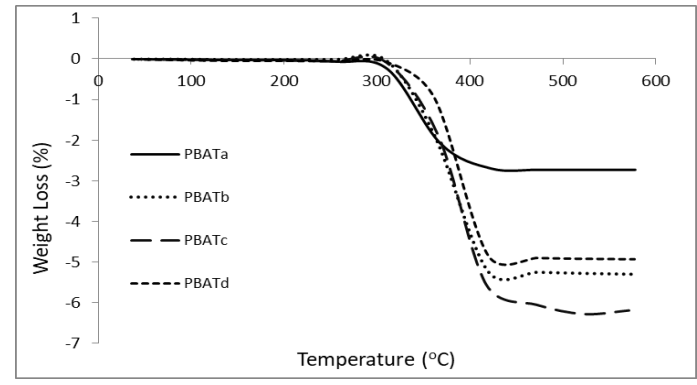

Figure 4 TGA Graph of Each Sample PBAT to Temperature

it can be seen that the graph shows that all samples undergo a single decomposition. The degradation temperature range is in the temperature range of $280-370^{\circ} \mathrm{C}$. At a temperature of $105-200^{\circ} \mathrm{C}$, the composite loses mass, which is the evaporation of the moisture content in the composite. Linyun et al. (2020)

PLA/Coir composite mixture with the addition of bentonite has a better thermal stability ability than without bentonite. PCa samples were degraded at a temperature of $280.21^{\circ} \mathrm{C}$. While the PBAUa, PBAUb, PBAUc and PBAUd samples began to degrade at temperatures of $282.11^{\circ} \mathrm{C}, 289.76^{\circ} \mathrm{C}, 305.54^{\circ} \mathrm{C}$ and $315.04^{\circ} \mathrm{C}$, then samples of PBATa, PBATb, PBATc and PBATd began to degrade at $320^{\circ} \mathrm{C}$ each. $119^{\circ} \mathrm{C}, 349.99^{\circ} \mathrm{C}, 357.76^{\circ} \mathrm{C}$ and $370.51^{\circ} \mathrm{C}$ the results of this study indicate that the addition of this AT bentonite filler mixture has succeeded in increasing the thermal and mechanical stability of AU bentonite which is characterized by an increase in the degradation temperature. The increase in temperature in the composite is caused by the loss of polymer and filler bonds, making it difficult to break and the decomposition of the material becomes slower. Rodchanasuripron et al. (2020), Joowon et al. (2020)

\subsection{SCANNING ELECTRON MICROSCOPE ANALYSIS OF BENTONITE}

Scanning Electron Microscope is a type of electron microscope that depicts the surface of a sample through a scanning process using a high-energy beam of electrons in a raster scan pattern. Yingfeng et al. (2020) Electrons interact with atoms that will make the sample generate signals and provide information about the sample's surface topography, composition and other properties such as electrical conductivity. SEM analysis was carried out to determine the morphology of the single polymer PLA/Coir, PLA/Coir with the addition of AU bentonite and AT bentonite. In principle, if there is a change, for example, a fracture, indentation and a difference in the material structure, the energy tends to change. Tsung-Han et al. 
(2020) The changed energy can be emitted, reflected, absorbed, and converted into a wave function of electrons that can be captured and read on a SEM photo. SEM analysis results show differences in the morphology of the single polymer PLA/Coir, PLA/Coir with the addition of fillers of AU bentonite and AT bentonite which have been modified using cationic surfactants. SEM analysis results can be seen in Figure 5.

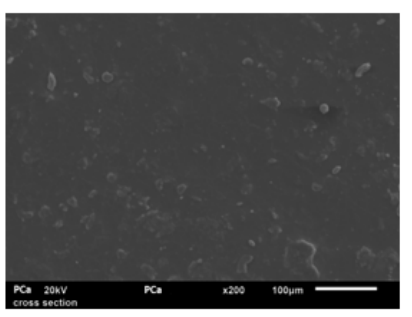

(a)

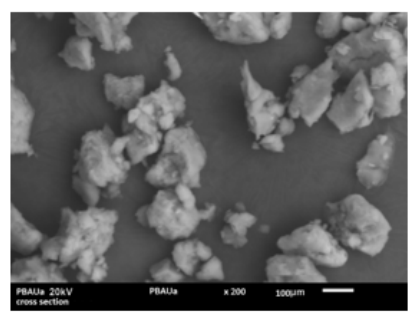

(b)

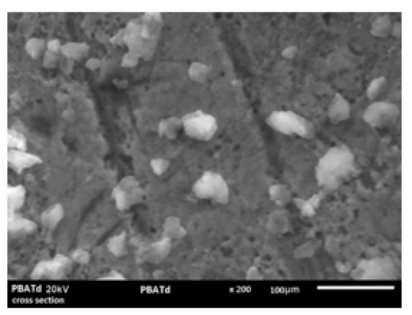

(c)

Figure 5 SEM analysis results (a) PCa (b) PBAUa (c) PBATd

SEM images of PLA/Coir single polymer, North Aceh bentonite and Central Aceh bentonite were taken at a magnification of 1,000 X. Based on the results of surface morphological characterization seen from the SEM results, the surface structure of PLA/Coir single polymer, North Aceh bentonite and Central Aceh bentonite has a surface that is In contrast, the surface structure of the PCa sample is more homogeneous because there is no bentonite filler mixture, for the PBATd sample, the surface structure is smoother and more homogeneous compared to the PBAUa sample. The large particle surface size indicates a good combination quality with the addition of filler to the PLA/Coir polymer. SEM images of PLA/Coir single polymer, North Aceh bentonite and Central Aceh bentonite were taken at a magnification of $1,000 \mathrm{X}$. Based on the results of surface morphological characterization seen from the SEM results, the surface structure of PLA/Coir single polymer, North Aceh bentonite and Central Aceh bentonite has a surface that is In contrast, the surface structure of the PCa sample is more homogeneous because there is no bentonite filler mixture, for the PBATd sample, the surface structure is smoother and more homogeneous compared to the PBAUa sample. The large particle surface size indicates a good combination quality with the addition of filler to the PLA/Coir polymer. Observing the internal morphology of the material using a Scanning Electron Microscope (SEM) in the fault area indicates the presence of voids and fiber breaks in the internal part of the microcomposite material. Some fibers experience pull-out when tensile and bending tests are carried out. Sung et al. (2017)

\subsection{BENDING TEST ANALYSIS}

The bending test or flexure test is applied to materials that receive bending loads, such as metal springs, ceramic floors, stone, plastic wood, and concrete girders. In general, the bending testing process has two test methods, namely: three points bending and four-point bending. Nurdiana et al. (2013), Bhasn ey et al. (2020) To determine the flexural strength of a material can be done by testing the flexural of the composite material. The flexural test refers to the ASTM D790 standard with static test conditions. Flexural strength or bending strength is the largest flexural stress that can be accepted due to external loading without undergoing major deformation or failure. The amount of flexural strength depends on the type of 
material and loading. As a result of the bending test, the upper part of the test object experiences stress, while the lower part will experience tensile stress.

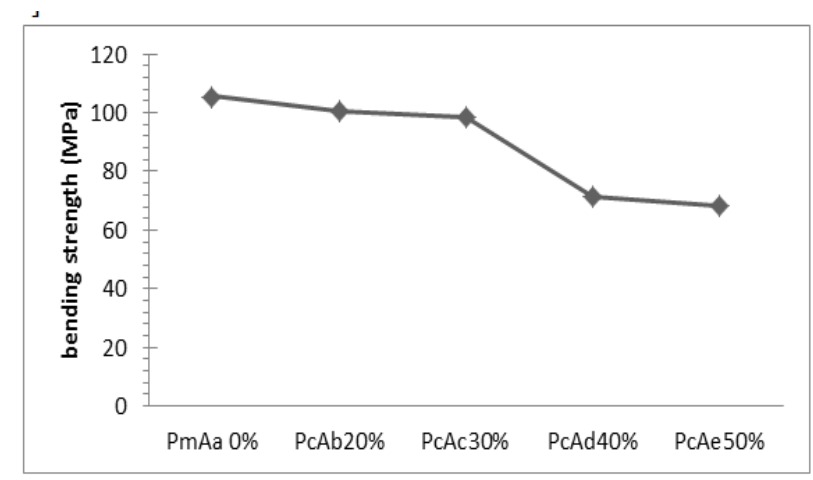

Figure 6 Pure PLA bending test results and fiber volume fraction

The highest bending strength of the composite material as a result of this study was owned by a $0 \%$ unreinforced material of $105.61 \mathrm{Mpa}$ and a composite material with a $20 \%$ mass fraction of coconut fiber, which was $100.76 \mathrm{Mpa}$. The addition of the mass fraction of coco fiber resulted in a decrease in the value of the bending strength of the synthesized composite material.

\section{CONCLUSIONS AND RECOMMENDATIONS}

The results showed that the PBATd sample produced the best bacterial test value, 65 colonies/gram in 12 days. In the tensile strength test of PLA/CoirBentonite, nanocomposites were able to produce a better tensile strength value compared to pure PLA/Coir without mixing with bentonite filler. The value of the PBATc sample tensile strength is $65 \mathrm{MPa}$. The tensile strength value increases with the addition of the filler concentration, but the tensile strength value will decrease if an excess concentration or overload of filler is added. PLA/Coir composite mixtures with the addition of bentonite have better thermal stability capabilities. PBATd samples were degraded at $370.51^{\circ} \mathrm{C}$ compared to PCa samples degraded at $280.21^{\circ} \mathrm{C}$. While the PBAUa, PBAUb samples, PBAUc and PBAUd began to degrade at temperatures of $282.11^{\circ} \mathrm{C}, 289.76^{\circ} \mathrm{C}, 305.54^{\circ} \mathrm{C}$ and $315.04^{\circ} \mathrm{C}$, respectively. For the single polymer surface structure of PLA/Coir, Aceh Utara bentonite and Aceh Tengah bentonite have different surfaces, the surface of the PCa sample is more homogeneous and looks very scattered compared to PBAU and PBAT, the surface structure can still have fine lumps but the PBAT sample is visible the structure is more homogeneous and smoother than the PBAU sample. The type of bentonite that is best used as a filler in this study is bentonite from the Central Aceh region because of its higher montmorillonite content and greater swelling power compared to bentonite from the North Aceh region. Aceh Utara bentonite and Aceh Tengah bentonite have different surfaces. The surface of the PCa sample is more homogeneous and looks very scattered compared to PBAU and PBAT, the surface structure can still contain fine lumps but the PBAT sample looks more homogeneous and smoother than the PBAU sample. The type of bentonite that is best used as a

filler in this study is bentonite from the Central Aceh region because of its higher montmorillonite content and greater swelling power compared to bentonite from the North Aceh region. 


\section{ACKNOWLEDGEMENTS}

The author expresses his gratitude and highest appreciation to Sincere appreciation to the Ministry of Research, Technology and Higher Education of the Republic of Indonesia and Lhokseumawe State Polytechnic which has funded through grants number: 850/E4.1/AK.04.PT/PNL/2021.

\section{REFERENCES}

Ajeng.; Dianita ; (2017) Effect of Fiber Mass Fraction on Mechanical Properties of Coconut Coir Fiber Reinforced Composite Materials and Polypropylene Matrix. Essay. Jember: University of Jember.

Aniber, B.; Stanly,R.; Muhammad, R. (2015) Comparative study of tensile properties in thermoplastic\& thermoset polymer composites.International Journal of Applied Engineering Research. 10, 10109-10113.

Astika, I.M.;Dwijana, I.G.K. (2018) Characteristics of tensile properties and fracture modes of polymer composites with coconut fiber reinforcement. Mechanical Engineering Dynamics..4(2). 2088-088.

Azhar, E.; Equbal, I.; AnjumBadruddin, I.; Algahtanic, A. (2021) A critical insight into the use of FDM for production of EDM electrode.Journal of Alexandria Engineering Jour. 1-10. Retrieved from https://doi.org/10.1016/j.aej.2021.09.033

Bhasney, S.M.;Mondal, K.;Kumar, A.;Katiyar, V.; (2020) Effect of microcrystalline cellulose fibers [MCC] on morphological and crystalline behavior of high density polyethylene [HDPE]/polylactic acid [PLA] mixtures. Compost. science. Technol. $19,1-23$.

Bino, P.;Stanly, J.R.; Ramachandran, M. (2015) Analysis of the mechanical properties of glass and carbon fiber reinforced polymer materials. International Journal of Applied Engineering Research. 10, 10387-10391.

Chern, C.; Ibrahim, N.; Wan, M.; Lalu, Y.; Zainuddin, N. (2013) Improved Mechanical and Thermal Properties of Polylactic Acid/Polycaprolactone Blends by Hydrophilic Nanoclay.Indian Journal of Material Science. 11, 816503. Retrieved from https://doi.org/10.1155/2013/816503

Dong, Y.;Ghataura, A.;Takagi, H.; Hazim.;Haroosh, J.; Antonio N.; Nakagaito.; Kin-Tak Lau.; (2014) Polylactic acid (PLA) biocomposites reinforced with coir fibres: Evaluation of mechanical performance and multifunctional properties. Composites Part A: Applied Science and Manufacturing. 63. 76-84. Retrieved from https://doi.org/10.1016/j.compositesa.2014.04.003

Douglas,P.; Albadarin, A.; Al-Muhtaseb,A.H.; Mangwandi, C.; Walker, G. (2015) Thermo-Mechanical Properties of Poly e-Caprolactone/Poly L-Lactic Mixtures: Addition of Nalidixic Acid and Polyethylene Glycol Additives.Journal of Mechanical Behavior of Biomedical Materials. 45, 15416. Retrieved from https://doi.org/10.1016/j.jmbbm.2015.01.022

Fahmi, H.; Hermansyah, H. (2011) Effect of Fiber Orientation on Polyester Resin Composites/Pineapple Leaf Fibers on Tensile Strength. Journal of Mechanical Engineering. 1. 46-52.

Ginting, E.M.; (2016) Mechanical Properties Of HDPE Thermoplastic Nano Composites With Multiple Fillers. Unimed Press. 1-4.

Hasnan, M.A.; Husseinsyah, S.; Ying, L.B.; Rahman, M. (2015) Chemical modification of palm kernel shield filled polylactic acis biocomposite films. Journal of 
Palm Kernel/PLA Films Bioresources.11 (3), 6639-6648. Retrieved from https://doi.org/10.15376/biores.11.3.6639-6648

Hin,L.; Aussler, H.; Vogel, R.; Brunig, H.; Heinrich, G.; Werner, C, (2012) Hollowfiber is made of a poly (3-hydroxybutyrate)/poly-e-caprolactone mixture. Express Polymer Letters. 7, 643-652. Retrieved from https://doi.org/10.3144/expresspolymlett.2011.62

Jaafar, J.;Siregar,J.p.;Tezara, C.;Hamdan.; Rihayat, T. (2019) A review of important considerations in the compression molding process of short natural fiber composites. The International Journal of Advanced Manufacturing Technology. 105, 1-13. Retrieved from https://doi.org/10.1007/s00170019-04466-8

Joowon, Park.; Hyoryong, L.; Hyeonwoo, K.; Sukho, P.; (2020) Magnetically steerable manipulator with variable stiffness using graphene polylactic acid for minimally invasive surgery. Sensors and Actuators A: Physical. 309. 09244247. Retrieved from https://doi.org/10.1016/j.sna.2020.112032

Kurzina, I.A.; Laput,O.A.; Zuza,D.A.; Vasenina, M.C.; Salvadori, K.P.; Savkin, D.N.; Lytkina, V.V.; Botvin, M.P.; Kalashnikov.; (2020) Surface property modification of biocompatible material based on polylactic acid by ion implantation, Surface and Coatings Technology .388, 0257-8972. Retrieved from https://doi.org/10.1016/j.surfcoat.2020.125529

Linyun, Z.; Chongxing, H.; Yangfan X.; Haohe H.; Hui, Z.; Jian, W.; Shuangfei, W.; (2020) Synthesis and characterization of antibacterial polylactic acid film incorporated with cinnamaldehyde inclusions for fruit packaging. International Journal of Biological Macromolecules. 164.4547-4555. Retrieved from https://doi.org/10.1016/j.ijbiomac.2020.09.065

Makhrus, A. (2015) Modification of the Hydraulic Mechanical System Bending Test Equipment and Test Results for COR Iron Materials. Semarang. Diploma III Study Program in Mechanical Engineering, Diponegoro University. 1, 11-13.

Maryanti, B.; Sonief, A.A.; Wahyudi, S.; (2011) Effect of Alkalization of Coconut FiberPolyester Composite on Tensile Strength. Journal of Mechanical Engineering. 2, 123-129. Retrieved from https://rekayasamesin.ub.ac.id/index.php/rm/article/view/129/124

Najafi, N.; Heuzey, M.C.; Carreau, P.J. (2012) Polylactide (PLA)-Clay Nanocomposites Prepared By Melt Compounding In The Presence of A Chain Extende. Composites Science and Technology. 72, 608-615. Retrieved from https://doi.org/10.1016/j.compscitech.2012.01.005

Nurdiana, Z.; Lubis.;Vonnisa M.; (2013) Determination of Tensile Strength of Epoxy Composite Material with Rockwool Fiber Filler Experimentally. Dynamic Journal. 1, 13, 0216-7492.

Piekarska, K.;Piorkowska, E.; Bojda J.; (2017) Effect of matrix crystallinity, filler grain size and modification on properties of PLA/calcium carbonate composites. PolymTest..62, 203-209., Retrieved from https://doi.org/10.1016/j.polymertesting.2017.06.025

Pradeep, P.; Edwin, R.D.; (2015) Muhammad,R. Mechanical Characterization of hemp fiber on glass and carbon fiber reinforced polymer composites. International Journal of Applied Engineering Research. 10, 11, 1039210396.

Purwaningsih,E.; Supartono,S.; Harjono, H. (2012) Transesterification reaction of coconut oil with methanol using bentonite as catalyst. Indonesian Journal of Chemical Science. 1(2),133-139 
Qamara, A.; Anwara, Z.; Alib, H.; Imran, S.; Shaukat, R.; Mujtaba, M. (2021) Experimental investigation of dispersion stability and thermophysical properties of ZnO/DIW nanofluids for heat transfer applications. Journal of Alexandria Engineering Journal.1-16. Retrieved from https://doi.org/10.1016/j.aej.2021.09.028

Rihayat, T.; Suryani, S.; Zaini, H.; Rahmawati, C.A.; Irawan, Y. (2017) Synthesis, characterization and microbial protection of palm oil based polyurethane/bentonite/chitosan as paint and coating material. Proceeding 2nd International Conference Sustainable and Renewable Energy Engineering. 1 , 10-13. Retrieved from https://doi.org/10.1109/ICSREE.2017.7951501

Rihayat, T.;Salim, S.;Arlina, A. ; Z Fona.; R Jalal.; PN Alam.; M Sami.; J Syarif.; N Juhan. (2018) Determination of CEC value (cation exchange capacity) of bentonites from North Aceh and Bener Meriah, Aceh Province Indonesia using three methods. IOP Conference Series: Materials Science and Engineering. 334, 17. Retrieved from https://doi.org/10.1088/1757-899X/334/1/012054

Rodchanasuripron, W.;Seadan, M.;Suttiruengwong, S.; (2020) Properties of nonwoven polylactic acid fibers prepared by the rotational jet spinning method. Materials Today Sustainability.10. Retrieved from https://doi.org/10.1016/j.mtsust.2020.100046

Shumigin, D.; Tarasova, E.; Krumme, A.; (2011) Meier Rheological and mechanical properties of poly (lactic) acid/cellulose and LDPE/cellulose composite. Journal of material science (medziagotyra). 17 (1), 32-37. Retrieved from https://doi.org/10.5755/j01.ms.17.1.245

Sung, S.H.; Chang, Y.;Han, J.; (2017) Development of polylactic acid nanocomposite films reinforced withcellulose nanocrystals derived from coffee silverskin. Carbohydrate Polymers.169. 495-503. Retrieved from https://doi.org/10.1016/j.carbpol.2017.04.037

Suryani, Harry Agusnar, Basuki Wirjosentono, Teuku Rihayat, Nurhanifa. (2018). Thermal degradation of Aceh's bentonite reinforced poly lactic acid (PLA) based on renewable resources for packaging application. AIP Conference Proceedings, Vol. 2049, 1-5. Retrieved from https://doi.org/10.1063/1.5082445

Suryani, S.; Agusnar, H.; Wirjosentono,B.; Rihayat, T.; Nugroho, A.R. (2016) Synthesis and Characterization of Nature-Based Poly Lactic Acid Using Tmah (II) Catalyst Octoate. Proceedings of the 2016 National Seminar on Chemistry and Chemistry Education. 16-20.

Syamani, F.A.; Kurniawan, Y.D.; Suryanegara, L. (2014) Cellulose fibers from oil palm fronds reinforced polylactic acid composite.Proceeding of the ASEAN conference on science and technology. 1-5. Retrieved from https://d1wqtxts1xzle7.cloudfront.net/56979305/CELLULOSE_FIBERS_F ROM_OIL_PALM_FRONDS_RE20180711-9775-1do8lwa-with-cover-pagev2.pdf?Expires $=1637919721 \&$ Signature $=$ dCJ8nM-CRlzSbHvOGs1uqp8kD9Rwy6wZvNNx2mLz2BQum4G5tolSpBMCCS 7hSXT V6juNaER0U8UxbFTZY7u 2GrqDKViI6AyHMgNqX0vte NveqY Twet2yvhVRpvQWH-

I2fv7pW12XiH3U0VK6LSVbgXo5PSS3A1xIToSs4MXTYseDOaI3vwde60iSH 0701f 45kTb YjN4E3kSg8ZGm9gua1MVvXn91Ms8BVfRmPamvQoIWnF2 4UJI0QQfApL-

N120DuSPTgI8QhKcElH2CBeteafhd65iaC6mwk 69U2c1P0UdVJZqtb0BK 
MW5lRA2frnKyFl0mJ5gx7bkVw_\&Key-Pair-

Id=APKAJLOHF5GGSLRBV4ZA

Tawakkal, I.; Talib, R.; Abdan, K.; Ling, C.N. (2012) Mechanical and physical properties of kenaf derived cellulose (KDC) - filled polylactic acid (PLA) composites. Journal of PLA-Kenaf Properties Bioresources. 7 (2), 16431655. Retrieved from https://doi.org/10.15376/biores.7.2.1643-1655

Teuku Rihayat, Suryani, Satriananda, Ridwan, Nurhanifa, Alfian Putra, Nia Audina, Muhammad Yunus, Sariadi, Safari, Ramzi Jalal, Nani Siska Putri Khan, Saifuddin. (2018). Influence of coating polyurethane with mixture of bentonite and chitosan nanocomposites. AIP Conference Proceedings, Vol. 2049, 1-6. Retrieved from https://doi.org/10.1063/1.5082425

Teuku Rihayat, Suryani, Zaimahwati, Salmyah, Sariadi, Fitria, Satriananda, Alfian Putra, Zahra Fona, Juanda, Raudah, Aida Safitri, Mawaddah, Nurhanifa, Shafira Riskina and Wildan Syahputra. (2019). Composition on Essential Oil Extraction from Lemongrass Fragrant by Microwave Air Hydro Distillation Method to Perfume Dermatitis Production. IOP Conference Series: Materials Science and Engineering, Vol.506, 1-6. Retrieved from https://doi.org/10.1088/1757-899X/506/1/012053

Tsung-Han, Y.; Yu-Hsun, S.; Hsuan-Hao, H.; Hsin-Jung, T.; Wen-Kuang, H.; (2020) Amorphous fraction controlled mechanical and optical properties of polylactic acid below glass transition temperature. Polymer Testing. 2020.91. 0142-9418. Retrieved from https://doi.org/10.1016/j.polymertesting.2020.106731

Valerio, O.; Misra, M.; Mohanty, A.K. (2018) Statistical design of sustainable thermoplastic mixtures of poly(glycerol succinate-co-maleate) (PGSMA), poly(lactic acid) (PLA) and poly(butylene succinate) (PBS). Polym. Test. 65, 420-428. Retrieved from https://doi.org/10.1016/j.polymertesting.2017.12.018

Yingfeng, Z.; Kang, C.; Ping, L.; Xiaoyu, H.; Wenhao, L.; Yiqiang, W.; (2020) Effect of nano-SiO2 on the compatibility interface and properties of polylactic acidgrafted-bamboo fiber/polylactic acid composite. International Journal of Biological Macromolecules. 157. 177-186. Retrieved from https://doi.org/10.1016/j.ijbiomac.2020.04.205

Yusoff, R.B.;Takagi, H.;Nakagaito, A.N.; (2016) Tensile and flexural properties of polylactic acid-based hybrid green composites reinforced by kenaf, bamboo and coir fibers. Industrial Crops and Products.94. Retrieved from https://doi.org/10.1016/j.indcrop.2016.09.017

Zulkifli.; Rihayat, T.; Suryani,S.; Facraniah.; Ummi, Habibah.; Nia, A.;Fauzi, T.; Nurhanifa.; Zaimahwati.; Rosalina. (2018) Purification process of jelantah oil using active charcoal kepok's banana.AIP Conference Proceedings. 1, 1-6. Retrieved from https://doi.org/10.1063/1.5082427 